\title{
Quotidien bactériologique.
}
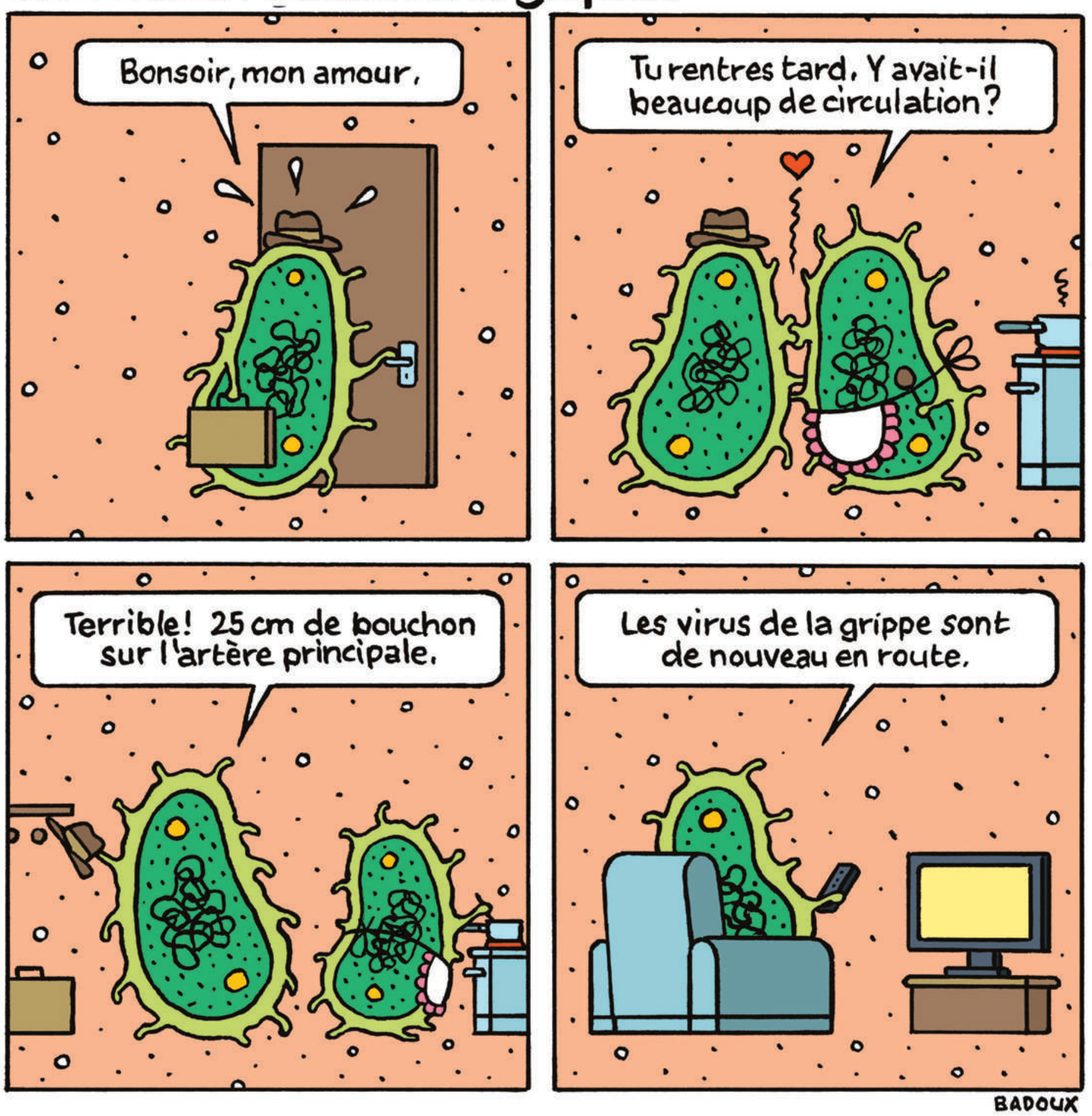